\title{
DIFFERENCES IN MUSCLE STRENGTH OF THE DOMINANT AND NON-DOMINANT LEG OF HIGH PERFORMANCE FEMALE ATHLETES
}

\author{
Roberta Sadauskaitè-Zarembiene் $\dot{1}^{1}$, Renata Žumbakytė-Šermukšniené $\dot{e}^{1,2}$, \\ Mantas Mickevičius ${ }^{2}$ \\ Lithuanian University of Health Sciences, Medical Academyl', Kaunas, Lithuania \\ Lithuanian Sports University', Kaunas, Lithuania
}

\begin{abstract}
Research background and hypothesis. According research literature, the imbalance of hip muscles in the dominant and non-dominant leg can cause wear and tear of the knee joint or tendinitis. Therefore the study was carried out to determine whether there were differences in muscle strength and if muscle differences had influence on knee joints of dominant and non-dominant legs for high performance women athletes.

Research aim was to compare muscle strength of knee flexor, extensor and hip abductor, adductor muscles of the dominant and non-dominant legs for high performance female athletes.

Research methods. There were 53 high performance female athletes participating in the study, whose maximum strength of flexor and extensor muscles of knee, as well as abductor and adductor muscles of hip had been measured using a dynamometer MMT - Manual Muscle Tester.

Research results. The strength of flexor and extensor muscles of knee of the non-dominant leg was significantly higher than that of the dominant leg. There was no statistically significant difference in strength of abductor and adductor muscles of the dominant and non-dominant leg.

Discussion and conclusions. The strength of flexor and extensor muscles of knee of non-dominating leg for high performance female athletes was significantly greater than muscle strength of the dominant leg. There was no statistically significant difference in the strength of the abductor and adductor muscles of hip of the dominant and non-dominant leg. It is advisable to develop exercises to strengthen these muscle groups in order to prevent knee injury in the future.
\end{abstract}

Keywords: knee flexors, knee extensors, hip abductors, hip adduction.

\section{INTRODUCTION}

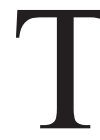

The difference in strength of the same muscles of one and the other leg depends on each different branch of sports (Coombs et al., 2002). According to K. R. Ford and the co-authors (2003), the dominance of lower limb is a stronger dominance of one limb, manifested by increased dynamic power control, thus causing imbalance of muscles and asymmetries between the two extremities. The load attributable to the dominant limb may increase joint tension of that limb.

According to C. Jacobs and the co-authors (2005), the dominance of one limb may be the cause of weakness of the opposite limb. It has been established that the non-dominant limb reduces the ability to accommodate large external forces during exercise. Therefore, the authors have drawn attention to the dominance of one leg, as it has been related to the strength and function of leg muscles.

However, several studies have shown there has been no significant difference in strength of flexor 
and extensor muscles of knee between the dominant and non-dominant leg (Nadler et al., 2002). However, the study carried out by M. Hägglund et al. (2012) has revealed the fact that not only the difference of strength of muscles of the same hip, but also the difference higher by 10 percent of muscle strength between the dominant and non-dominant leg may increase the risk of injury for athletes.

According to C. Jacobs and C. G. Mattacole (2004), there can be differences of muscle strength between the dominant and non-dominant leg in joints of hip and knee seen while performing functional tasks, such as a canter. There is a highly possible functional difference in the abductor and adductor muscles of the dominant leg.

The studies have shown (Lanshammar, Ribon, 2011; Hägglund et al., 2012) that there may be a significant physiological difference between the strength of hip muscles. The majority of athletes, having this difference in muscle strength, have had complaints about it. What is more, in order to address this problem it is very important to create adequate rehabilitation objective. It should also be noted that there are, however, distinguished details in the literature about the difference of strength of the hip muscles between the dominant and nondominant leg. This fact has encouraged the high performance female athletes to carry out the study.

The aim of the study was to compare muscle strength of knee flexor, extensor and hip abductor, adductor muscles of the dominant and nondominant leg of high performance female athletes.

\section{RESEARCH METHODS}

There were 53 high performance female athletes participating in the study at Kaunas Center of Sports Medicine. The athletes had been engaged in sports (handball and basketball) for $12 \pm 4.36$ years; 5 times a week for 1.5 hours (Table). The study was carried out in accordance with the Declaration of Helsinki.

Table. Characteristics of the study group

\begin{tabular}{|c|c|c|c|c|}
\hline Group & Age, yrs & Height, m & $\begin{array}{c}\text { Weight, } \\
\text { kg }\end{array}$ & $\begin{array}{c}\text { Sports } \\
\text { experience, } \\
\text { yrs }\end{array}$ \\
\hline $\begin{array}{c}53 \text { high } \\
\text { performance } \\
\text { female } \\
\text { athletes }\end{array}$ & $22 \pm 4.10$ & $1.74 \pm 0.07$ & $69 \pm 8.19$ & $12 \pm 4.36$ \\
\hline
\end{tabular}

The strength of hip muscles was measured using Nicholas Manual Muscle Tester (Sisto,
Dyson-Hudson, 2007). We measured the maximum strength of flexor and extensor muscles of knee, and abductor and adductor muscles of hip of the dominant and non-dominant leg (Figure 1).

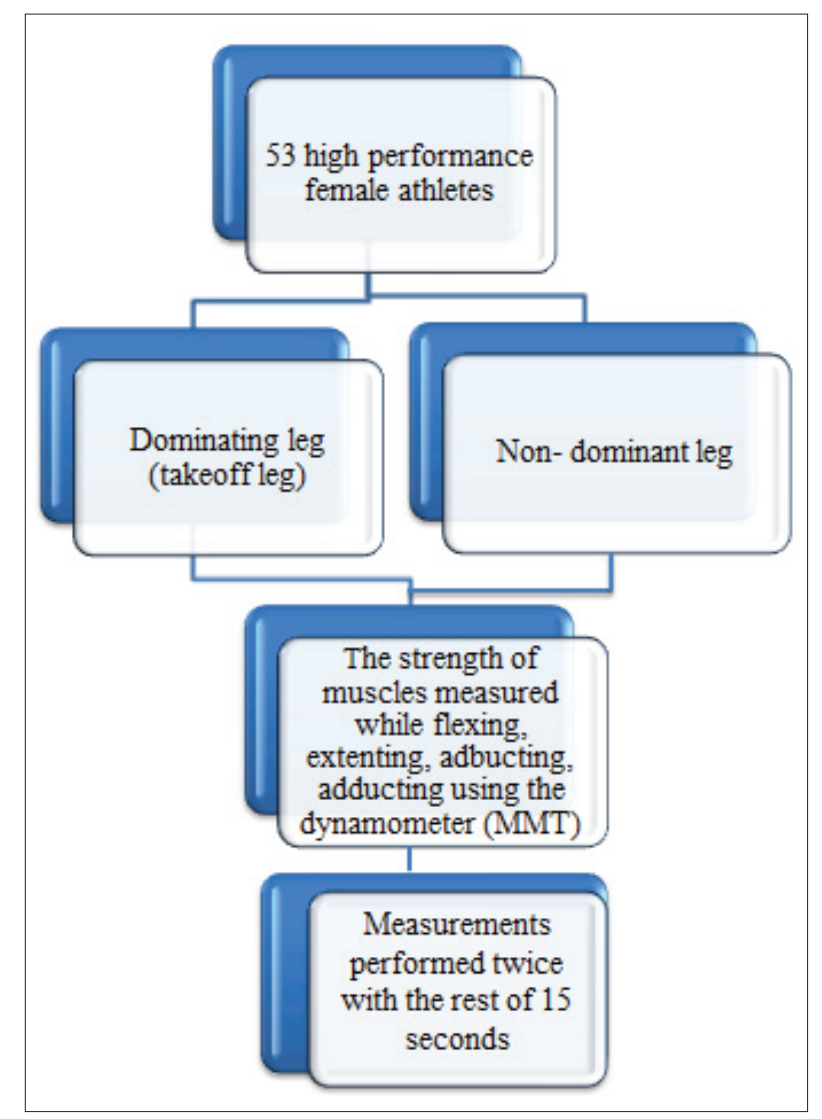

Figure 1. Course of the study

The study was carried before the workout. The initial position of the person examined in the knee extension was as follows: the person examined sat on the couch with the leg bent over the knee at the ankle joint at 90 degrees, the back was straight, and feet did not touch the ground. At the moment when the person examined was extending the knee, the tester provided resistance by placing the dynamometer at the distal part of the knee. The person had to overcome the resistance force provided by the tester by extending the knee at the maximum capacity within 3 seconds.

The initial position of the person examined in the kneeflexion was as follows: the person examined sat on the couch with the leg bent over the knee at the ankle joint at 90 degrees, the back was straight, and feet did not touch the ground. At the moment when the person examined was flexing the knee, the tester provided resistance by placing the dynamometer at the rear part of the knee. At the moment of knee flexion the tester had to stabilize the back and the leg of the person examined. The person had to overcome the resistance force provided by the tester 
by flexing the knee at the maximum capacity within 3 seconds (Dunn, Iversen, 2003).

The initial position of the person examined in the hip adduction was as follows: the person examined lied on the opposite side than the examined leg; one hand was kept under the head, the other was put on the edge of the couch. The other lower leg of the person was bent at 90 degrees, and it was being extended when examined. The researcher captured the hip of the person examined with one hand and provided resistance by placing the dynamometer at the distal end of the fibula. The person had to overcome the resistance force provided by the researcher by pulling back the knee at the maximum capacity within 3 seconds (Fredericdon, Cookingham, 2000).

The initial position of the person examined in the hip abduction was as follows: the persons examined lied on the same side as the leg examined; one hand was kept under the head, the other was put on the edge of the couch. The other lower leg of the person was bent at 90 degrees. The researcher captured the hip of the person examined with one hand and provided resistance by placing the Dynamometer at the distal end of the tibia. The person had to overcome the resistance force provided by the researcher by pulling in the knee at the maximum capacity within 3 seconds. (Fredericdon, Cookingham, 2000). In case the athletes used the surrounding (compensatory) muscles in examination, the testing would be stopped and started over again. The reliability of information remained high until the strength measured $10 \%$ less than the force provided by the examiner (Fredericdon, Cookingham, 2000). Every move was performed twice with the rest of 15 seconds. Calculation of the average of two results was performed.

Mathematical Statistics. We used SPSS program for the data analysis. The paired Student's $t$ test was applied to compare the dependent samples, when the data did not differ from a normal distribution; and the non-parametric Wilcoxon test was used to compare the data to establish a significant difference. Differences at $p<0.05$ were considered to be statistically significant. Results were presented as the arithmetic mean $(\mathrm{m}) \pm$ the standard deviation of the average estimate.

\section{RESEARCH RESULTS}

According to the results obtained, the strength of extensor muscles of knee of the non-dominant leg was $4.7 \mathrm{~kg} \pm 0.65$ and the dominant leg $13.8 \mathrm{~kg} \pm 0.62 \mathrm{~kg}$. The study revealed that the strength of muscles of the non-dominant leg was statistically significantly higher $(\mathrm{p}<0.05)$ than that of the dominant leg (Figure 2).

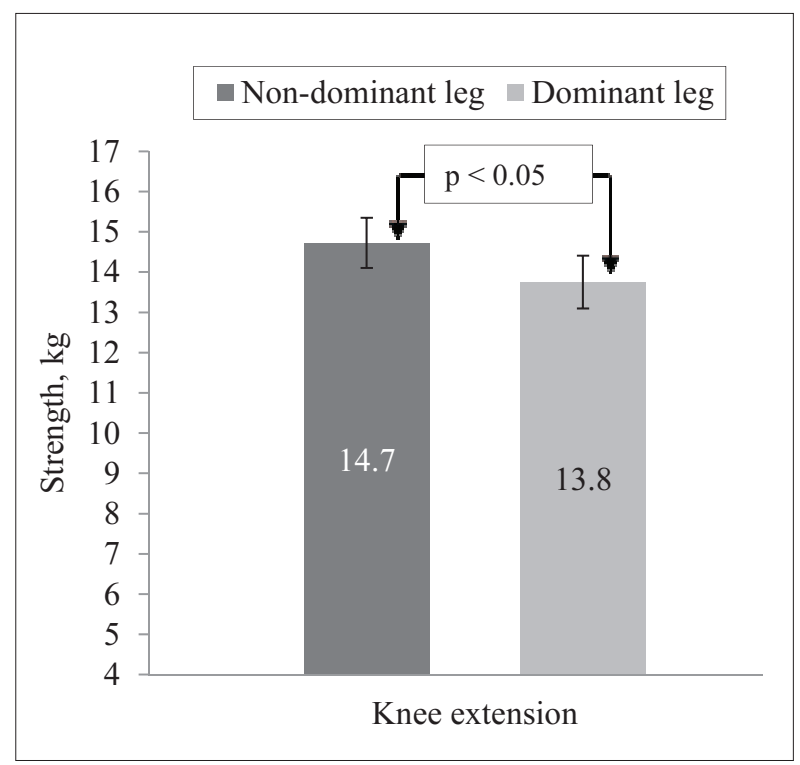

Figure 2. Change in the strength (kg) of muscles of the dominant and non-dominant leg after the knee extension

Change in the strength $(\mathrm{kg})$ of muscles of the dominant and non-dominant leg can be seen in Figure 3. According to the results obtained, the strength of flexor muscles of knee of the nondominant leg was $1.7 \mathrm{~kg} \pm 0.65$ and dominant leg $-11 \mathrm{~kg} \pm 0.61$. The study revealed that the strength of muscles of the non-dominant leg was statistically significantly higher $(p<0.05)$ than that of the dominant leg.

The strength of adductor muscles of hip of the dominant leg $(8 \mathrm{~kg} \pm 0.55)$ had an insignificant trend to grow compared to the strength of adductor muscles of hip of the non-dominant leg $(7.7 \mathrm{~kg} \pm 0.33)$. There was no significant difference in the dominant and non-dominant leg comparing the strength of the adductor muscles of hip of the dominant and non-dominant leg $(p>0.05)$ (Figure 4). 


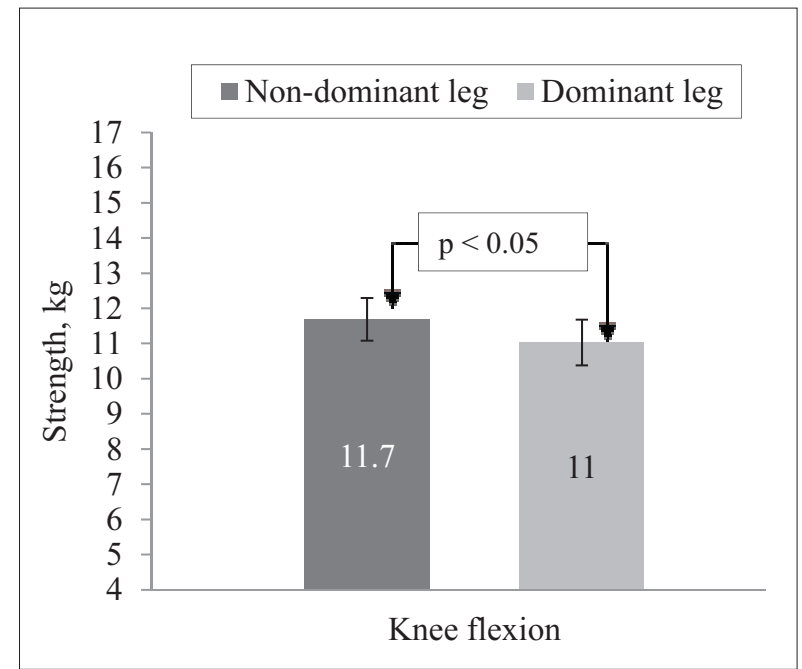

Figure 3. Change in the strength $(\mathrm{kg})$ of muscles of the dominant and non-dominant leg of the female athletes after the knee flexion

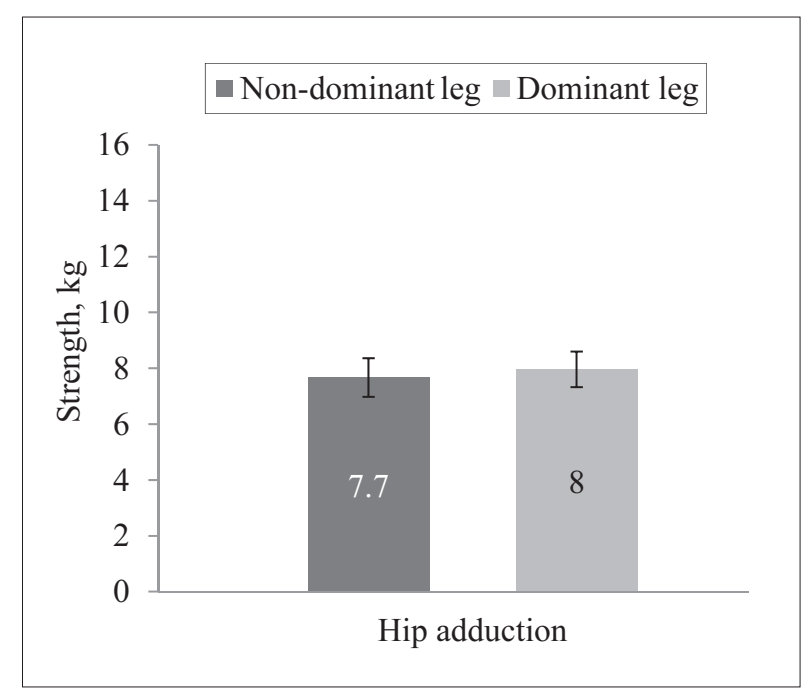

Figure 4. Change in the strength $(\mathrm{kg})$ of muscles of the dominant and non-dominant leg of the female athletes after the hip adduction

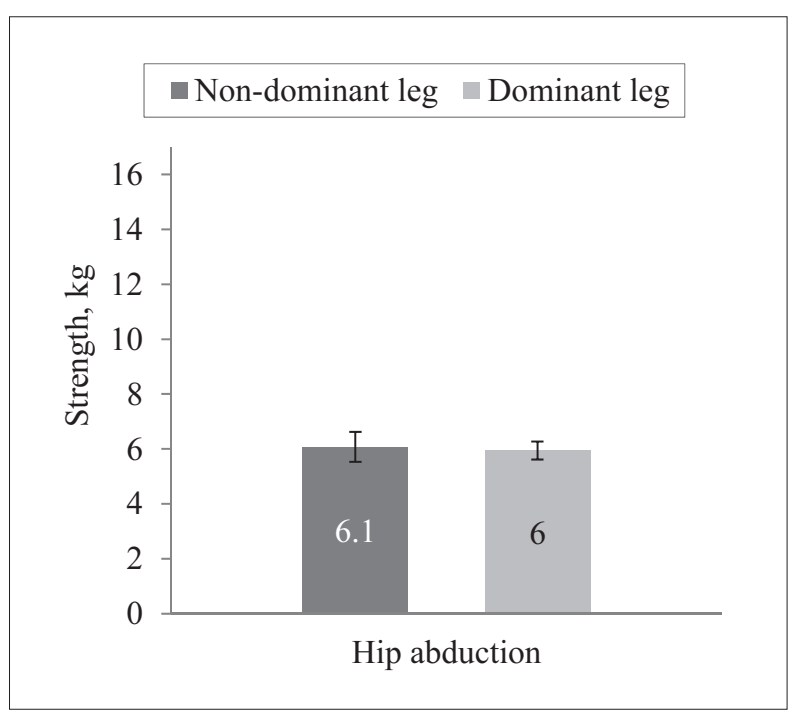

Figure 5. Change in the strength $(\mathrm{kg})$ of muscles of the dominant and non-dominant leg of the female athletes after the hip abduction
Change in the strength of muscles of adductor muscles of hip of the dominant and non-dominant leg can be seen in Figure 5. The strength of the abductor muscles of hip of the non-dominant $(6.1 \mathrm{~kg} \pm 0.69)$ and the strength of the abductor muscles of the dominant leg $(6 \mathrm{~kg} \pm 0.64)$ had an insignificant tendency to increase. There was no significant difference in the dominant and nondominant leg in comparing the strength of the abductor muscles of hip of the dominant and nondominant leg $(p>0.05)$.

\section{DISCUSSION}

Branches of team sports are multifaceted, requiring a well-developed physical condition to be able to play successfully (Chaouachi et al., 2009). A. Chaouachi and the others (2009) have also found the strength, power, agility and speed to be important factors for high performance athletes. According to the study conducted, the basketball players who perform exercise for muscle strength and flexibility do not to face imbalances of flexor and extensor muscles of knee between the dominant and non-dominant leg (Schiltz et al., 2009). It is, therefore, important to track differences in muscle strength and balance of high performance athletes in order to avoid knee injuries in the future.

Our study found out a significant difference of strength of flexor and extensor muscles of knee between the dominant and non-dominant leg of high performance female athletes. The strength of muscles of non-dominant leg was found to be statistically significantly greater than the strength of the dominant leg after the measurement of the flexor and extensor muscles of knee for the athletes. According to K. Lanshammar and E. L. Ribon (2011), there is also statistically significant asymmetry in muscle strength between the dominant and non-dominant leg of female athletes. However, their study revealed the strength of flexor muscles of knee to be greater by $8.6 \%$ in the non-dominant leg, while the strength of extensor muscles of knee would be greater by $5.3 \%$ in the dominant leg. According to the conducted study, the interrelationship of the hip muscles was greater in the non-dominant leg. Physical activity has been stated to have particularly significant impact on this fact.

The study results may have been apparently affected by excessive exercise and the dominant leg fatigue. Regardless the branch of sports, the dominant leg of all the female athletes examined 
is the take-off leg which helps to perform the high jump or long jump. If athletes are right handed, this hand would be used as the fine motor skill hand. Hence, the right leg would also be used as fine motor skills leg (for instance, a ball kicking), these are daily movements performed by the non-dominant leg and not to be performed at the time of some sports event. It is believed that the dominant leg is to be used for skills, while the non-dominant leg is used to achieve those skills (Rahnama et al., 2005).

According to P. W. Kong and the others (2010), however, the conducted study showed that forty physically active women would perform muscle strengthening exercises for quadriceps and biceps for both legs at least 3 times a week. The dominant leg would have a greater difference in the strength of hip muscles, compared to the non-dominating leg. Physical exercise is believed to strengthen the weaker leg and make it dominant while doing the exercises (Kong et al., 2010).

Our study also revealed the fact that the strength of adductor muscle of the hip would be tendentiously increasing in the dominant leg, while there the strength of abductor muscles of the hip would increase, however, there would be no statistically significant differences found in the strength of abductor and adductor muscles of the hip in the dominant and non-dominant leg. According to the study carried out by C. Jacob and the others (2007), the strength of abductor and adductor muscles of the hip would not have any change between the right and left leg. This suggests the athletes examined would not have any muscle imbalances between the one and other leg.

However, the author states, if the hip adductor muscle imbalance in power athletes in the future can lead to chronic knee injuries, including pain in the patellar joint surface of the femur and tibia, the tendon friction syndrome. According to K. McCurdy and G. Langford (2005), the imbalance of the muscles of the lower extremities is related to the increasing risk of damage occurring in a later period of training. According to $\mathrm{K}$. Thorborg and the others (2011), the strength of abductor and adductor muscles of the hip in the dominating leg would be $14 \%$ greater than in the non-dominant leg. The results are believed to have been influenced by the nature of sports and specifics of the exercises performed providing workload on the adductor and abductor muscles. The greater workload is possible for adductor muscles of the hip while performing more lateral movement along with abductor muscles of the non-dominant leg. Specificity of sports such as basketball and handball include not only flexing and extension movements within hip (running forward or backward), but abduction and adduction movements as well while performing the leg movements from side to side). In our case, there is imbalance of muscles of the hip visible in the dominant and non-dominant leg, so it is advisable to develop exercises to strengthen these muscle groups in order to prevent knee injury in the future.

\section{CONCLUSIONS AND PERSPECTIVES}

1. The strength of flexor and extensor muscles of the thigh of high performance athletes is significantly greater in the dominant leg compared to the non-dominant leg.

2. There is no statistically significant difference in abductor and adductor muscles of the hip in the strength of muscles of the dominant and the nondominant leg.

\section{REFERENCES}

Coombs, R., Garbutt, G. (2002). Developments in the use of the hamstring/quadriceps ratio for the assessment of muscle balance. Journal of Medicine Science and Sports Exercise, 12 (1), 56-62.

Chaouachi, A., Brughelli, M., Chamari, K. et al. (2009). Lower limb maximal dynamic strength and agility determinants in elite basketball players. Journal of Strength and Conditioning Research, 23 (5), 1570-1577.

Dunn, J., Iversen, M. (2003). Interrater reliability of knee muscle forces obtained by hand-held dynamometer from elderly subjects with degenerative back pain. Journal of Geriatric Physical Therapy, 26 (3), 436-442.

Ford, K. R., Myer, G. D., Hewett, T. E. (2003). Valgus knee motion during landing in high school female and male basketball players. Journal of Sports Science and Medicine, 35, 1745-1750.

Fredericdon, M., Cookingham, L. (2000). Hip abductor weakness in distance runners with iliotibial band syndrome. Clinical Journal of Sport Medicine, 10 (1), 169-175.

Hägglund, M., Waldén, M., Ekstrand, J. (2012). Risk factors for lower extremity muscle injury in professional soccer: The UEFA Injury Study. The American Journal of Sports Medicine, 41 (2), 327-335.

Jacobs, C., Mattacola, C. G. (2004). Eccentric hip strength and kinematic differences between the dominant and nondominant legs of men and women during a hopping task. Journal of Athletic Training, 39 (2), 34-35. 
Jacobs, C., Uhl, T. L., Seeley, M., Sterling, W., Goodrich, L. (2005). Strength and fatigability of the dominant and nondominant hip abductors. Journal of Athletic Training, 40 (3), 203-206.

Kong, P. W., Burns, S. F. (2010). Bilateral difference in hamstrings to quadriceps ratio in healthy males and females. Journal of Physical Therapy in Sport, 11 (5) $12-17$.

Lanshammar, K., Ribom, E. L. (2011). Differences in muscle strength in dominant and non-dominant leg in females aged 20-39 years: A population-based study. Journal of Physical Therapy in Sport, 12 (6), 76-79.

McCurdy, K., Langford, G. (2005). Comparison of unilateral squat strength between the dominant and non-dominant leg in men and women. Journal of Sports Science and Medicine, 4, 153-159.

Nadler, S. F., Malanga, G. A., Bartoli, L. A. et al. (2002). Hip muscle imbalance and low back pain in athletes:
Influence of core strengthening. Journal of Medicine Science and Sports Exercise, 34, 9-16.

Rahnama, N., Lees, A., Bambaecichi, E. (2005). A comparison of muscle strength and flexibility between the preferred and non-preferred leg in English soccer players. Journal of Ergonomics, 48 (11-14), 1568-1575. Schiltz, M., Lehance, P. T., Maquet, D. et al. (2009). Explosive strength imbalances in professional basketball players. Journal of Athletic Training, 44 (1), 39-47.

Sisto, S. A., Dysoon-Hudson, T. (2007). Dynamometry testing in spinal cord injury. Journal of Rehabilitation Research \& Development, 44 (1), 123-136.

Thorborg, K., Couppé, C., Petersen, J., Magnusson, S. P., Hölmich, P. (2011). Eccentric hip adduction and abduction strength in elite soccer players and matched controls: A cross-sectional study. British Journal of Sports Medicine, 45 (1), 10-13.

\title{
DIDELIO MEISTRIŠKUMO ŽAIDIMO ŠAKŲ SPORTININKIŲ DOMINUOJANČIOS IR NEDOMINUOJANČIOS KOJOS RAUMENŲ JËGOS SKIRTUMAI
}

\author{
Roberta Sadauskaitė-Zarembienè ${ }^{1}$, Renata Žumbakytė-Šermukšnienè $\dot{1}^{1,2}$, \\ Mantas Mickevičius ${ }^{2}$ \\ Lietuvos sveikatos mokslu universitetas, Medicinos akademija ${ }^{1}$, Kaunas, Lietuva \\ Lietuvos sporto universitetas ${ }^{2}$, Kaunas, Lietuva
}

\section{SANTRAUKA}

Tyrimo pagrindimas ir hipoteze். Literatūroje rašoma, kad dominuojančios ir nedominuojančios kojos šlaunies raumenų disbalansas gali sukelti kelio sąnario nusidèvẻjimą ar sausgyslių uždegimą. Todèl norèta patikrinti, ar yra raumenų jègos skirtumų ir kaip jie veikia didelio meistriškumo sportininkių dominuojančios ir nedominuojančios kojos kelio sąnarius.

Tikslas - palyginti didelio meistriškumo žaidimo šakų sportininkių dominuojančios ir nedominuojančios kojos blauzdos tiesiamujuc, lenkiamujų ir dubens atitraukiamujų, pritraukiamujų raumenų jègą.

Metodai. Buvo tiriamos didelio meistriškumo žaidimo šakų sportininkès $(\mathrm{n}=53)$, kurioms buvo matuojama dominuojančios ir nedominuojančios kojos maksimalioji blauzdos lenkiamujų, tiesiamujų raumenų ir dubens atitraukiamuju, pritraukiamujų raumenų jèga (dinamometru MMT - Manual Muscle Tester).

Rezultatai. Nedominuojančios kojos blauzdos lenkiamujų ir tiesiamujų raumenų jèga (kg) statistiškai reikšmingai didesnè $(p<0,05)$ nei dominuojančios. Sportininkių dominuojančios ir nedominuojančios kojos dubens pritraukiamujų ir atitraukiamujų raumenų jègos $(\mathrm{kg})$ statistiškai reikšmingo skirtumo nebuvo $(\mathrm{p}>0,05)$.

Aptarimas ir išvados. Didelio meistriškumo žaidimo šakų sportininkių blauzdos tiesiamujų ir lenkiamuju raumenų jèga statistiškai reikšmingai didesnè nedominuojančios kojos nei dominuojančios. Taip pat nėra statistiškai reikšmingo skirtumo tarp dominuojančios ir nedominuojančios kojos dubens atitraukiamujų ir pritraukiamuju raumenų jėgos. Norint išvengti kelio pažeidimų, patartina naudoti šių raumenų grupių stiprinimo pratimus.

Raktažodžiai: kelio lenkiamieji, kelio tiesiamieji, klubo atitraukiamieji, klubo pritraukiamieji raumenys.

Gauta 2013 m. sausio 17 d.

Received on January 17, 2013

Priimta 2013 m. kovo $8 \mathrm{~d}$.

Accepted on March 8, 2013
Corresponding author Roberta Sadauskaitè-Zarembienè Lithuanian University of Health Sciences

A. Mickevičiaus str. 9, LT-44307 Kaunas

Lithuania

Tel +37061856468

E-mail r.ssadauskaite@gmail.com 